\title{
Тихомиров В.А., Рыбак Д.В.
}

Общественно-политические ток-шоу на российском телевидении как инструмент политической пропаганды

Забайкальский государственньий университет

(Россия, Чита)

doi: $10.18411 /$ spc-26-06-2020-04

idsp: sciencepublic-26-06-2020-04

\section{Аннотация}

В статье осуществлена исследование формата «общественно-политическое токшоу» на российском телевидении. Автором данный вид телевизионных передач рассматривается как инструмент политической пропаганды. В работе рассмотрено понятие ток-шоу, выделены основные черты общественно-политических ток-шоу, проанализированы основные телепередачи, связанные с общественно политическим обозрением, проведен анализ некоторых эпизодов общественно-политических ток-шоу из разных передач и каналов российского телевидения.

Ключевые слова: общественно-политическое вещание, ток-шоу, общественнополитическое ток-шоу, рейтинг, российское телевидение, политическая пропаганда, инструменты политической пропаганды.

\section{Abstract}

The article studies the format of "socio-political talk show" on Russian television. The author considers this type of TV programs as a tool of political propaganda. The paper considers the concept of talk shows, highlights the main features of socio-political talk shows, analyzes the main TV programs related to the socio-political review, analyzes some episodes of socio-political talk shows from various programs and channels of Russian television.

Keywords: socio-political broadcasting, talk show, socio-political talk show, rating, Russian television, political propaganda, tools of political propaganda.

Современное российское телевидение все чаще делает ставку на проведение различного вида общественно-политических ток-шоу. Их появление на общественном телевидении России и стремительная эволюция была обусловлена обострением внешнеполитических отношений России и стран Запада в связи с кризисом на Украине и возвращением Республики Крым в состав Российской Федерации.

Эти исторические события оказались драматичными для России и в виду еще более усугубившийся изоляции от стран, так называемого, цивилизованного мира, и в виду того, что внутри государства обострились противоречия, расколовшие общества на поддерживающих отсоединение Крыма от Украины и на не одобряющих данные события. Углубляющий раскол в обществе, назревавший довольно долго до этих событий, в связи с долгим присутствием В.В. Путина у власти, потребовал усиления государственной пропагандистской машины, а телевидение как наиболее эффективный механизм этой политики стал использовать все доступные ему средства в виде общественно-политических ток-шоу как инструмента политической пропаганды.

А.Л. Коданиной и А.В. Рязановы был проведен анализ телевизионного эфира главных каналов страны - «Первого канала», «Россия 1 и НТВ в период с 2016 по 2018 гг. 
Нами был проведён анализ телевизионного эфира главных каналов страны - «Первого канала», «России 1» и НТВ за период с 2016 по 2018 гт. Для начала проведено сравнение телевизионной сетки каждого канала по времени, уделяемому политическим ток-шоу за последние три года на 1 ноября (будние дни).

\begin{tabular}{|c|c|c|c|}
\hline & 1 ноября 2016 & 1 ноября 2017 & 1 ноября 2018 \\
\hline $\begin{array}{l}\text { «Первый } \\
\text { канал» }\end{array}$ & $\begin{array}{l}3 \text { часа 25 минут («Время } \\
\text { покажет»: 13:20-14:00, } \\
14: 15-15: 00,15: 15-16: 00, \\
\text { повтор 01:05-02:30) }\end{array}$ & $\begin{array}{l}4 \text { часа } 35 \text { минут («Время } \\
\text { покажет»: 12:15-15:00, } \\
\text { 17:00-18:00, повтор 00:30- } \\
01: 35)\end{array}$ & $\begin{array}{l}5 \text { часов 10 минут («Время } \\
\text { покажет): 12:15-15:00, } \\
\text { 17:00-18:00, 18:25-18:50; } \\
\text { «Большая игра»: 22:45- } \\
23: 45)\end{array}$ \\
\hline «Россия 1» & $\begin{array}{llr}4 \text { часа } & 10 & \text { минут («60 } \\
\text { минут»: } & 18: 50-20: 00 ; \\
\text { «Вечер } & \text { с } & \text { Владимиром } \\
\text { Соловьёвым»: } 23: 40-02: 40)\end{array}$ & $\begin{array}{l}4 \text { часа } 30 \text { минут («60 минут: } \\
13: 00-14: 00, \quad 19: 00-20: 00 ; \\
\text { «Вечер с } \text {;ладимиром } \\
\text { Соловьёвым»: 23:15-01:45) }\end{array}$ & $\begin{array}{lrrr}5 & \text { часов } & 5 & \text { минут } \\
(« 60 & \text { минут»: } & 12: 50- \\
14: 00, & 18: 50-20: 00 ; \\
\text { «Вечер с } & \text { Владимиром } \\
\text { Соловьёвым»: } & 23: 20- \\
02: 05) & \end{array}$ \\
\hline «HTВ» & $\begin{array}{l}2 \text { часа («Место встречи): } \\
14: 00-16: 00)\end{array}$ & $\begin{array}{l}4 \text { часа } 25 \text { минут («Место } \\
\text { встречи): } 14: 00-16: 00 \text {, } \\
16: 30-17: 00 \text {, повтор } 00: 45- \\
02: 40)\end{array}$ & $\begin{array}{lr}4 \text { часа } 40 \text { минут («Место } \\
\text { встречи»: } 14: 00-16: 00, \\
16: 30-17: 15, \\
01: 20-03: 15)\end{array}$ \\
\hline
\end{tabular}

Для начала было проведено сравнение телевизионной сетки каждого канала по времени, отведенного общественно-политическим ток-шоу за последние три года на момент 1 ноября (в будние дни) (Таблица 1) [1].

Таблица 1.

Увеличение времени показа общественно-политических ток-иоу за последние три года

\begin{tabular}{|c|c|c|c|}
\hline & 1 ноября 2016 & 1 ноября 2017 & 1 ноября 2018 \\
\hline $\begin{array}{l}\text { «Первый } \\
\text { канал» }\end{array}$ & $\begin{array}{c}3 \text { часа } 25 \text { минут («Время } \\
\text { покажет»: 13:20-14:00, } \\
\text { 14:15-15:00, 15:15-16:00, } \\
\text { повтор 01:05-02:30) }\end{array}$ & $\begin{array}{c}4 \text { часа } 35 \text { минут («Время } \\
\text { покажет»: 12:15-15:00, } \\
\text { 17:00-18:00, повтор 00:30- } \\
\text { 01:35) }\end{array}$ & $\begin{array}{c}5 \text { часов } 10 \text { минут («Время } \\
\text { покажет»:12:15.-15:00, 17:00- } \\
\text { 18:00, 18:25-18:50 } \\
\text { «Большая игра»: 22:45- } \\
\text { 23:45) }\end{array}$ \\
\hline «Россия 1» & $\begin{array}{c}4 \text { часа } 10 \text { минут («60 } \\
\text { минут»:18:50-20:00; } \\
\text { «Вечер с Владимиром } \\
\text { Соловьевы»: 23:40-02:40) }\end{array}$ & $\begin{array}{c}4 \text { часа } 30 \text { минут («60 } \\
\text { минут»): } \\
\text { 13:00-14:00, 19:00-20:00; } \\
\text { «Вечер с Владимиром } \\
\text { Соловьевы»: 23:15-01:45) }\end{array}$ & $\begin{array}{c}5 \text { часов } 5 \text { минут («60 минут»: } \\
\text { 12:50- 14:00, 18:50-20:00; } \\
\text { «Вечер с Владимиром } \\
\text { Соловьевым»: (23:20- } \\
\text { 02:05) }\end{array}$ \\
\hline «HTB» & $\begin{array}{c}2 \text { часа («Место встречи»: } \\
\text { 14:00-16:00) }\end{array}$ & \begin{tabular}{|c|}
4 часа 25 минут («Место \\
встречи»: 14:00-16:00, 16:30- \\
17:00, повтор 00:45-02:40)
\end{tabular} & $\begin{array}{c}4 \text { часа } 40 \text { минут («Место } \\
\text { встречи»: 14:00-16:00, 16:30- } \\
17: 15 \text {, повтор 01:20-03:15) }\end{array}$ \\
\hline
\end{tabular}

Как видим из сетки вещания только три года показа одних и тех же передач, время их трансляции увеличилось в некоторых случаях в два раза, в других случаях на час с лишним. Этот факт говорит только о том, что передачи имеют своего зрителя, с одной стороны, с другой стороны политическая пропаганда в России набирает обороты, увеличивая количество часов для телевещания необходимых для государства идей.

Роль общественно-политических ток-шоу, безусловно, в реализации политической пропаганды довольно значительна, так как сам формат ток-шоу предполагает своего рода игру в демократию, когда в студию приглашаются специалисты из различных областей знания, к тому же обладающие подчас противоположными политическими взглядами. Такими мы видим, политические передачи «Время покажет» на 1 канале, «Вечер с Владимиром Соловьевым», «Место встречи» на НТВ, «60 минут» на 1 канале, «Право голоса» (ТВ-Центр) и др.

Между тем при внимательном рассмотрении и ежедневном просмотре оказывается, что общественно-политические ток-шоу из передачи в передачу повторяют набившие оскомину пропагандистские приемы, такие как распределение ролей, как в итальянской комедии дель арто: «злобный либерал» (Игорь Чубайс, 
Григорий Амнуэль, Александр Сытин), «туповатые украинские эксперты» (Вячеслав Ковтун, Олеся Яхно), «крикливые и недалекие заграничные эксперты» (Майкл Бом, Якуб Корейба, Томаш Мацейчук), «пламенные патриоты» (Леонид Калашников, Алексей Пушков, Сергей Марков). Безусловно, нельзя сказать, что каждый из этих персонажей «играет роль». Замысел постановщиков этих ток-шоу учитывает правила режиссуры, когда любое действо становится интересным при столкновении противоположностей.

Интересным представляется, что каждая из этих передач рассчитана на определенную аудиторию. К примеру, передача Шейнина «Время покажет» рассчитана на более простоватую аудиторию, не претендующую на интеллигентность и интеллект, а аудитория Андрея Норкина - это публика с более тонким и интеллигентным вкусом. Каждый канал делает ставку на свою аудиторию и занимает ту нишу, которая еще не занята другими каналами.

Важным является подбор ведущих на общественно-политические ток-шоу. В передаче «Время покажет» был осуществлен довольно, на первый взгляд, неожиданный выбор ведущих. С одной стороны, Первый канал - это канал страны, официальный, позиционирующий себя как главный, всегда считавшийся образцом культуры и высокого уровня профессионализма. С другой стороны, приглашение таких ведущих, как Артем Шейнин и Анатолий Кузичёв, которые ведут себя крайне эмоционально, подчас крикливо, выражаются не только просторечиями, но могут допустить и нецензурную лексику, допускают весьма резкие и грубые реплики в адрес собеседника. Встречались случаи и грубого выталкивания гостей и студии. Слегка хамоватый Артем Шейнин играет роль выразителя народных чаяний, при этом остается стойким защитником государственной власти. Кузичев и Стриженова выполняют чисто бутафорские роли, уравновешивая темперамент Шейнина.

На канале НТВ образ Андрея Норкина не случайно выбран для передачи «Место встречи». Российская пропаганда не может упустить случай оказывать свое воздействие на интеллигентную и думающую публику через создаваемый образ довольно умного, ироничного, высоко профессионального журналиста, каким является А. Норкин. При этом передача «Место встречи» несколько лет подряд удерживает рейтинг на первом месте. Его смотрят $12,7 \%$ среди россиян $18+$. Это выше, чем у Первого канала $(11,4 \%)$ и «России $1 »(12 \%)^{*}$. Параллельно на Первом канале идёт программа «Время покажет», а на «России 1» - сериалы [2].

К достаточно агрессивной политической пропаганде можно отнести передачу «60 минут» с Ольгой Скабеевой и Евгением Поповым. Образы ведущих - беспощадны, саркастичны, напористы, жестки. Вместе с Владимиром Соловьевым и Дмитрием Киселевым, пожалуй, эти ведущие составляют костяк политической пропаганды России.

Одним из важных моментов анализа того, что общественно-политические токшоу на российском телевидении превратились в агрессивную политическую пропаганду, является лежащая на поверхности манера ведущих этих передач снисходительно и уничижительно относиться к той точке зрения, которая противоположна официальной. Экспертов демонстрируют в неприглядном виде, подбирая наиболее одиозных и эмоционально несдержанных политологов Александра Сытина, Григория Амнуэля, Игоря Чубайса. Между тем серьезных экспертов, которые бы высказывали объективную точку зрения, которая противоречила бы официальной статистике, никто в ток-шоу не приглашает. Даже, казалось бы, в такую передачу, которая отличалась относительной объективностью, как «Право голоса» или впоследствии «Своя правда» с Романом Бабаяном, приглашаются эксперты, которые не противоречат сложившимся клише «отрицательных» и «положительных» героев ток-шоу.

На наш взгляд, общественное телевидение со временем должно выходить на более высокий уровень проведения общественно-политических ток-шоу. Грубые приемы «обработки» телезрителя должны уйти в прошлое, уступив место 
выступлениям серьезных экспертов, глубоко занимающимся проблемам как внешнеполитических отношений, так и внутренней политики, постановке неразрешимых проблем актуальной действительности России. Зритель не нуждается в том, чтобы его использовали как удобный материал для достижения политических целей, он нуждается в серьезном и уважительном отношении к нему со стороны власти. К сожалению, в данное время политические ток-шоу служат только узконаправленным интересам политической пропаганды.

Таким образом, общественно-политические ток-шоу на российском телевидении как инструмент политической пропаганды обладают высокой степенью потенциального воздействия на зрителя, формируя при этом общественное мнение за счет использования довольно клишированных инструментов: распределения ролей на «хороших» и «плохих», «наших» и «не наших», подбирая на роли ведущих журналистов, отражающих менталитет той или иной демографической группы, подтасовывая факты, демонизируя оппозиционеров или экспертов «вражеской» скамейки. К сожалению, восприятие зрителя не может адекватно оценить приемы пропаганды, которые безотказно действуют на зрителя, формируя то мнение, которое удобно власти, при этом острейшие вопросы внутренней повестки государства или серьезные размышления по поводу внешнеполитических отношений остаются неразрешенными.

$$
* * *
$$

1. Коданина А.Л., Рязанов А.В. Роль и место общественно-политических ток-шоу на российском телевидении// Знак: проблемное поле медиаобразования. - 2020. - № 1 (35). - С . 151-157.

2. Россияне предпочитают «Место встречи»: Общественно-политическое ток-шоу НТВ «Место встречи» удерживает уверенное лидерство в слоте с 14.00 до 16.00.- URL: https://www.ntv.ru/novosti/1782378/ (дата обращения 14.06.2020).

\section{Чемоданова Т.Д. Гуманитарная повестка СМИ: жанровый аспект}

Нижегородский государственный университет им. Н.И. Лобачевского (Россия, Нижний Новгород)

doi: $10.18411 / s p c-26-06-2020-05$

idsp: sciencepublic-26-06-2020-05

\section{Аннотация}

Ввиду дегуманизации российского медиапространства в XXI веке особенно актуальными становятся вопросы, касающиеся популяризации социальной журналистики. Ее практическим инструментом можно назвать гуманитарную повестку дня в СМИ. В статье дается краткое объяснение этого феномена. Также приводятся результаты количественно-качественного контент-анализа журнала «Русский репортер», который формирует на своих страницах гуманитарную повестку дня. Ввиду того, что жанр - это как одна из главных категорий в теории журналистики, так и неотъемлемая часть практической деятельности журналистов, именно он стал объектом изучения. Статья раскрывает особенности использования различных жанров журналистами при написании материалов на гуманитарную тематику.

Ключевые слова: гуманитарная повестка дня, социальная журналистика, гуманитарная проблематика, жанры журналистики, жанровое своеобразие.

\section{Abstract}

Due to the process of dehumanization of Russian mediaspace in XXI century, the issues about popularization of social journalism are becoming more relevant. Setting humanitarian media agenda can be considered as a practical expression of social journalism. The article provided a short explanation of such the phenomenon. Results of content analysis of the journal "Russian Reporter" that sets humanitarian media agenda are demonstrated and discussed. As a genre is one of the most important categories in theoretical as well as practical 